\title{
ANALISA KEHANCURAN AGREGAT AKIBAT TUMBUKAN DALAM CAMPURAN ASPAL
}

\author{
M. Aminsyah ${ }^{1}$
}

\begin{abstract}
ABSTRAK
Salah satu transportasi yang berkembang di Indonesia adalah transpotasi darat, dimana kegiatan masyarakat tidak terlepas dari sarana dan prasarana transportasi tersebut. Perkerasan jalan yang bermutu baik sangat menunjang bagi kehidupan manusia untuk memenuhi kebutuhannya. Akibat dari kegiatan masyarakat ini menyebabkan terjadi pergerakan dari satu tempat ke tempat yang lain yang mempengaruhi volume lalu lintas. Volume lalu lintas berbanding lurus dengan kegiatan masyarakat. Semakin meningkat kegiatan masyarakat maka volume lalu lintas akan semakin tinggi. Dibutuhkan sarana dan prasarana transportasi yang memadai untuk menunjang kegiatan masyarakat, diantaranya melakukan peningkatan ketahanan jalan raya dalam menerima beban lalu lintas yang semakin tinggi. Hal tersebut dapat tercapai dengan meningkatkan mutu perkerasan jalan. Material utama pembentuk lapisan perkerasan jalan adalah agregat, yaitu 90-95\% dari berat campuran perkerasan. Agregat yang digunakan harus memenuhi persyaratan yang ada, disini lebih dikhususkan pada nilai kehancuran agregat (AIV) terhadap beban tumbuk. Penelitian ini menggunakan campuran Asphalt Concrete Wearing Course (AC-WC) gradasi halus. Campuran yang sesuai dengan spesifikasi dibandingkan dengan beberapa kombinasi nilai kehancuran agregat (AIV) yang berbeda. Berdasarkan penelitiaan ini diperoleh bahwa penggunaan nilai kehancuran agregat (AIV) terendah memberikan nilai kadar aspal optimum yang kecil, nilai stabilitas tinggi, kelelehan yang rendah, VIM yang besar, MQ yang kecil, dan VMA yang kecil dibandingkan dengan campuran lain.
\end{abstract}

Kata kunci : Perkerasan Jalan, AIV, AC - WC, Parameter Marshall

\section{PENDAHULUAN}

\subsection{Latar Belakang}

Jaringan jalan raya merupakan prasarana transportasi darat memegang peranan yang sangat penting dalam sektor perhubungan terutama untuk kesinambungan distribusi barang dan jasa (Hendarsin, 2000). Salah satu transportasi yang berkembang di Indonesia adalah transpotasi darat, dimana kegiatan masyarakat tidak terlepas dari sarana dan prasarana transportasi tersebut. Akibat dari kegiatan masyarakat ini menyebabkan terjadi pergerakan dari satu tempat ke tempat yang lain yang mempengaruhi volume lalu lintas. Volume lalu lintas berbanding lurus dengan kegiatan masyarakat. Semakin meningkat kegiatan masyarakat maka volume lalu lintas akan semakin tinggi.

Dengan demikian dibutuhkan sarana dan prasarana transportasi yang memadai untuk menunjang kegiatan masyarakat, diantaranya melakukan peningkatan ketahanan jalan raya dalam menerima beban lalu lintas yang semakin tinggi. Hal tersebut dapat tercapai dengan meningkatkan mutu perkerasan jalan.

\footnotetext{
${ }^{1}$ Staf Pengajar Jurusan Teknik Sipil Fakultas Teknik Universitas Andalas
} 
Material utama pembentuk lapisan perkerasan jalan adalah agregat, yaitu 90-95\% dari berat campuran perkerasan. Untuk mendapatkan perkerasan jalan yang memenuhi mutu yang diharapkan, maka perlu pengetahuan tentang sifat agregat. Disamping itu, pengetahuan tentang sifat bahan pengikat seperti aspal menjadi dasar untuk merancang campuran sesuai jenis perkerasan yang diinginkan (Sukirman, 2003). Selain itu, daya tahan agregat juga diperlukan agar mencapai mutu perkerasan yang diharapkan.

Daya tahan agregat merupakan ketahanan agregat terhadap adanya penurunan mutu akibat proses mekanis dan kimiawi. Agregat dapat mengalami degradasi, yaitu perubahan gradasi akibat pecahnya butir-butir agregat. Kehancuran agregat dapat disebabkan oleh proses mekanis, seperti gaya-gaya yang terjadi selama proses pelaksanaan perkerasan jalan (penimbunan, penghamparan, pemadatan), pelayanan terhadap beban lalu lintas, dan proses kimiawi, seperti pengaruh kelembaban, kepanasan, dan perubahan suhu sepanjang hari (Sukirman, 2003).

Pemeriksaan daya tahan agregat terhadap beban mekanis dilakukan dengan pengujian keausan menggunakan Mesin Los Angeles. Selain itu, juga dilakukan pengujian kehancuran agregat. Salah satunya, nilai kehancuran agregat terhadap tumbukan atau disebut dengan Aggregate Impact Value (AIV).

\subsection{Tujuan dan Manfaat}

\section{Tujuan Penelitian}

Penelitian ini bertujuan untuk mengetahui pengaruh nilai kehancuran agregat akibat beban tumbukan (Aggregate Impact Value) terhadap campuran aspal.

\section{Mafaat Penelitian}

Manfaat dari hasil penelitian ini dapat mengetahui batasan nilai kehancuran agregat (Aggregate Impact Value) yang yang baik untuk campuran aspal, dimana dapat meningkatkan mutu perkerasan jalan yang mendukung kelancaran transportasi bagi masyarakat.

\subsection{Batasan Masalah}

Batasan masalah dari penelitian ini adalah:

a. Penelitian ini terbatas skala laboratorium;

b. Jenis perkerasan adalah perkerasan lentur dengan spesifikasi Asphalt Concrete Wearing Course (AC-WC) gradasi halus;

c. Pengujian campuran aspal dengan alat Marshall;

d. Parameter-parameter pengujian alat marshall meliputi nilai stabilitas, kelelehan (flow), rongga dalam campuran (VIM), rongga antar mineral agregat (VMA), marshall quotient;

e. Jenis aspal yang digunakan adalah aspal keras panas penetrasi 60-70;

f. Agregat yang digunakan terdiri dari agregat kasar, agregat halus dan, filler. Agergat kasar diklasifikasikan menjadi empat agregat kasar dengan nilai kehancuran agregat (Aggregate Impact Value) yang berbeda-beda. Sedangkan filler yang digunakan adalah semen Portland.

\section{TINJAUAN PUSTAKA}

\subsection{Perkerasan Jalan}

Perkerasan jalan merupakan lapisan perkerasan yang terletak diantara lapisan tanah dasar dan roda kendaraan, yang berfungsi memberikan pelayanan kepada sarana transportasi, dan selama masa pelayanannya diharapkan tidak terjadi kerusakan bearti. Supaya perkerasan mempunyai daya dukung dan keawetan yang memadai, tetapi juga ekonomis, maka perkerasan jalan dibuat berlapis- 
lapis. Lapisan paling atas disebut juga sebagai lapisan permukaan, merupakan lapisan yang paling baik mutunya. Dibawahnya terdapat lapisan pondasi, yang terletak di atas tanah dasar yang telah dipadatkan.

\subsection{Konstruksi Perkerasan Jalan Raya}

Berdasarkan bahan pengikatnya konstruksi perkerasan jalan dapat dibedakan atas 3 jenis perkerasan antara lain :

a. Konstruksi perkerasan lentur (flexible pavement). Perkerasan lentur merupakan jenis perkerasan yang menggunakan aspal sebagai bahan pengikat. Lapis perkerasan ini bersifat memikul dan menyebarkan beban lalu lintas ke tanah dasar.

b. Konstruksi perkerasan kaku (rigid pavement). Merupakan perkerasan yang menggunakan semen sebagai bahan pengikat. Perkerasan ini memakai pelat beton dengan atau tanpa tulangan yang diletakan di atas tanah dasar dengan atau tanpa pondasi bawah.

c. Konstruksi perkerasan komposit (composite pavement). Merupakan perkerasan kaku yang dikombinasikan dengan perkerasan lentur.

\subsection{Konstruksi Perkerasan Lentur}

Konstruksi perkerasan lentur terdiri atas lapisan-lapisan yang diletakkan diatas tanah dasar yang telah dipadatkan.

1. Lapisan permukaan (Surface Course). Lapis permukaan struktur pekerasan lentur terdiri atas campuran mineral agregat dan bahan pengikat yang ditempatkan sebagai lapisan paling atas dan biasanya terletak di atas lapis pondasi.

2. Lapisan pondasi atas (Base Course). Lapis pondasi adalah bagian dari struktur perkerasan lentur yang terletak langsung di bawah lapis permukaan. Lapis pondasi dibangun di atas lapis pondasi bawah atau, jika tidak menggunakan lapis pondasi bawah, langsung di atas tanah dasar.

3. Lapisan pondasi bawah (Sub Base Course). Lapis pondasi bawah adalah bagian dari struktur perkerasan lentur yang terletak antara tanah dasar dan lapis pondasi. Biasanya terdiri atas lapisan dari material berbutir (granular material) yang dipadatkan, distabilisasi ataupun tidak, atau lapisan tanah yang distabilisasi.

4. Lapisan tanah dasar (Subgrade). Tanah dasar adalah permukaan tanah semula atau permukaan tanah galian atau permukaan tanah timbunan yang dipadatkan dan merupakan permukaan dasar untuk perletakan bagian - bagian perkerasan lainnya. Kekuatan dan keawetan konstruksi perkerasan

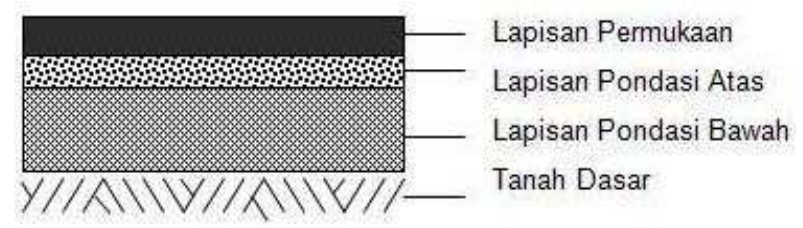

Gambar1. Susunan Lapis Konstruksi Perkerasan Lentur

\subsection{Beton Aspal}

Beton aspal adalah jenis perkerasan yang terdiri dari campuran agregat dan aspal, dengan atau tanpa bahan tambahan. Material - material pembentuk aspal dicampur di instalasi pencampur pada suhu tertentu, kemudian diangkut ke lokasi, dihamparkan, dan dipadatkan. Suhu pencampuran ditentukan berdasarkan jenis aspal yang akan digunakan. 


\subsubsection{Karakteristik Beton Aspal}

Karakteristik campuran yang harus dimiliki oleh beton aspal diantaranya stabilitas, keawetan atau durabilitas, kelenturan atau fleksibilitas, tahanan terhadap kelelahan (fatique resistance), kekesatan permukaan atau ketahanan geser, kedap air, dan kemudahan pelaksanaan.

a. Stabilitas adalah kemampuan perkerasan jalan merima beban lalu lintas tanpa terjadi perubahan bentuk tetap seperti gelombang, alur, dan bleeding. Jalan yang melayani volume lalu lintas yang tinggi dan dominan terdri dari kendaraan berat membutuhkan perkerasan jalan dengan stabilitas tinggi.

b. Keawetan atau durabilitas adalah kemampuan beton aspal menerima beban lalu lintas seperti berat kendaraan dan gesekan antara roda kendaraan dan permukaan jalan, serta menahan keausan akibat pengaruh cuaca dan iklim, seperti udara, air atau erubahan temperatur.

c. Kelenturan atau fleksibilitas adalah kemampuan beton aspal untuk menyesuaikan diri akibat penurunan dan pergerakan dari pondasi atau tanah dasar, tanpa terjadi retak. Fleksibilitas dapat ditingkatkan dengan agregat bergradasi terbuka dengan kadar aspal yang tinggi.

d. Ketahanan terhadap kelelahan (fatique resistance) adalah kemampuan beton aspal menerima lendutan berulang akibat repetisi beban, tanpa terjadinya kelelehan berupa alur dan retak.

e. Kekesatan/tahanan geser (skid resistance) adalah kemampuan permukaan beton aspal terutama pada kondisi basah, memberikan gaya gesek pada roda kendaraan sehingga kendaraan tidak tergelincir, ataupun slip.

f. Kedap air (impermeabilitas) adalah kemampuan beton aspal untuk tidak dapat dimasuki air ataupun udara ke dalam lapisan beton aspal.

g. Mudah pelaksanaan (workability) adalah kemampuan campuran beton aspal untuk mudah dihamparkan dan dipadatkan.

\subsubsection{Jenis - jenis Beton Aspal}

Jenis beton aspal dapat dibedakan berdasarkan suhu pencampuran material pembentuk beton aspal dan fungsi beton aspal.

Berdasarkan temperatur ketika mencampur dan memadatkan campuran, beton aspal dibedakan atas:

a. Beton aspal campuran panas (hotmix), adalah beton aspal yang material pembentuknya dicampur pada suhu pencampuran sekitar $140^{\circ} \mathrm{C}$;

b. Beton aspal campuran sedang (warm mix), adalah beton aspal yang material pembentuknya dicampur pada suhu pencampuran sekitar $60^{\circ} \mathrm{C}$;

c. Beton aspal campuran dingin (cold mix), adalah beton aspal yang material pembentuknya dicampur pada suhu pencampuran sekitar $60^{\circ} \mathrm{C}$;

Jenis beton aspal campuran panas yang ada di Indonesia diantaranya:

a. Laston (Lapisan Aspal Beton), dikenal dengan nama AC (Asphalt Concrete). Laston terdiri dari: AC-WC (Asphalt Concrete Wearing Course), AC-BC (Asphalt Concrete Wearing Course), AC-Base (Asphalt Concrete Base).

b. Lataston (Lapisan Tipis Aspal Beton), dikenal dengan nama HRS (Hot Rolled Sheet). Lataston terdiri dari HRS-WC dan HRS-Base.

c. Latasir (Lapisan Tipis Aspal Pasir), dikenal dengan nama HRSS (Hot Rolled Sand Sheet) yang digunakan untuk jalan - jalan dengan lalu lintas ringan. Latasir terdiri dari Latasir kelas A (HRSS-A) dan Latasir kelas B (HRSS-B).

d. Lapisan Perata adalah beton aspal yang digunakan sebagai lapisan perata dan pembentuk penampang melintang pada permukaan jalan lama.

VOLUME 9 NO. 2, OKTOBER 2013 | 53 
e. SMA (Split Mastic Asphalt), lapisan ini terutama digunakan untuk jalan-jalan dengan beban lalu lintas berat.

f. HSMA (High Stiffness Modulus Asphalt), adalah beton aspal yang mempergunakan aspal berpenetrasi rendah yaitu 30/45. Lapisan ini terutama digunakan untuk jalan-jalan dengan beban lalu lintas berat.

Lapis Aspal Beton (Laston) adalah suatu lapisan pada konstruksi jalan raya yang terdiri dari campuran aspal keras dan agregat yang bergradasi menerus, dicampur, dihampar dan dipadatkan dalam keadaan panas pada suhu tertentu. Lapis aspal beton umumnya digunakan untuk jalan - jalan dengan beban lalu lintas berat. Pembuatan Lapis Aspal Beton (Laston) dimaksudkan untuk mendapatkan suatu lapisan permukaan atau lapis antara pada perkerasan jalan raya yang mampu memberikan sumbangan daya dukung yang terukur serta berfungsi sebagai lapisan kedap air yang dapat melindungi konstruksi di bawahnya.

\subsection{Asphalt Concrete Wearing Course (AC-WC)}

Asphalt Concrete Wearing Course (AC-WC) merupakan laston sebagai lapisan aus yaitu lapisan perkerasan penahan roda, merupakan lapisan kedap air dan tahan terhadap cuaca.

Penggunaan AC-WC yaitu untuk lapis permukaan (paling atas) dalam perkerasan dan mempunyai tekstur yang paling halus dibandingkan dengan jenis laston lainnya. Gradasi butiran untuk campuran AC - WC gradasi halus dapat dilihat pada Tabel 1.

Tabel 1. Gradasi Agregat untuk Campuran AC - WC

\begin{tabular}{|c|c|c|c|}
\hline \multicolumn{2}{|c|}{ Ukuran Ayakan } & \multirow{2}{*}{$\begin{array}{l}\% \quad \text { Berat } \\
\text { yang lolos }\end{array}$} & \multirow{2}{*}{ Keterangan } \\
\hline ASTM & $\mathrm{mm}$ & & \\
\hline $3 / 4^{\prime \prime}$ & 19 & 100 & \multirow{5}{*}{ Agregat Kasar } \\
\hline $1 / 2 "$ & 12,5 & $90-100$ & \\
\hline $3 / 8 "$ & 9,5 & $72-90$ & \\
\hline no. 4 & 4,75 & $54-69$ & \\
\hline no. 8 & 2,36 & $39,1-53$ & \\
\hline no. 16 & 1,18 & $31,6-40$ & \multirow{5}{*}{ Agregat Halus } \\
\hline no. 30 & 0,6 & $23,1-30$ & \\
\hline no. 50 & 0,3 & $15,5-22$ & \\
\hline no. 100 & 0,150 & $9-15$ & \\
\hline no. 200 & 0,075 & $4-10$ & \\
\hline
\end{tabular}

Sumber : Kementerian Pekerjaan Umum, 2010

Untuk melihat layak atau tidaknya suatu campuran dan terpenuhinya persyaratan sesuai Spesifikasi Kementerian Pekerjaan Umum, yang mengacu pada parameter - Parameter Marshall pada Tabel 2 di bawah. Persyaratan Spesifikasi laston AC-WC dijadikan dasar kelayakan penggunaan agregat dalam penelitian ini. 
Tabel 2. Ketentuan Sifat - Sifat Campuran AC - WC

\begin{tabular}{|l|l|l|l|}
\hline \multirow{2}{*}{ Sifat - sifat campuran } & \multicolumn{2}{|l|}{ Lapis Aus } \\
\cline { 3 - 4 } & & 5,1 & 4,3 \\
\hline Kadar aspal efektif (\%) & & 75 \\
\hline Penyerapan aspal (\%) & Maks. & 1,2 \\
\hline $\begin{array}{l}\text { Jumlah tumbukan per } \\
\text { bidang }\end{array}$ & & Kasar \\
\hline $\begin{array}{l}\text { Rongga dalam campuran } \\
\text { (\%) }\end{array}$ & Min. & 3,5 \\
\cline { 2 - 3 } & Maks. & 5,0 \\
\hline $\begin{array}{l}\text { Rongga dalam agregat } \\
\text { (VMA) (\%) }\end{array}$ & Min. & 15 \\
\hline Rongga terisi aspal (\%) & Min. & 65 \\
\hline Stabilitas Marshall (kg) & Min. & 800 \\
\cline { 2 - 3 } & Maks. & - \\
\hline Pelelehan (mm) & Min. & 3 \\
\hline $\begin{array}{l}\text { Marshall } \\
\text { (kg/mm) }\end{array}$ & Min. & 250 \\
\hline Sumber : Ketient & \\
\hline
\end{tabular}

Sumber : Kementerian Pekerjaan Umum, 2010

\subsection{Bahan Penyusun Konstruksi}

\subsubsection{Agregat}

Agregat atau batu, atau granular material adalah material berbutir yang keras dan kompak. Agregat didefinisikan secara umum sebagai formasi kulit bumi yang keras dan padat. ASTM mendefinisikan agregat sebagai suatu bahan yang tediri dari mineral padat, berupa masa berukuran besar ataupun berupa fragmen - fragmen. Komponen utama dari struktur perkerasan jalan berdasarkan persentase volume, agregat merupakan komponen utama sehingga kualitas perkerasan jalan juga ditentukan oleh sifat agregat dan hasil campuran agregat dengan material lain.

\subsubsection{Aspal}

Sukirman mendefinisikan aspal sebagai material perekat (cementitious) bewarna hitam atau coklat tua, dengan unsur utama bitumen. Aspal dapat diperoleh di alam ataupun mrupakan residu dari pengilangan minyak bumi. Aspal adalah material pada temperatur ruang berbentuk padat sampai agak padat, dan bersifat termoplastis. Jadi, aspal akan mecair jika dipanaskan sampai temperatur tertentu, dan kembali membeku jika temperatur turun.

\subsection{Aggregate Impact Value (AIV)}

Pengujian kekuatan agregat terhadap tumbukan adalah proses dasar pada pembuatan agregat dimana seberapa besar kehancuran agregat setelah tumbukan (Aggregate Impact Value). Menurut BS 812 part 112: 1990 batas nilai kehancuran agregat (AIV) adalah 30\%.

\subsubsection{Peralatan}

a. Aggregate Impact Machine. Alat ini masih digerakkan secara manual dengan tenaga manusia

b. Berat total mesin tidak lebih dari $60 \mathrm{~kg}$ dan tidak kurang dari $40 \mathrm{~kg}$. Dasar mesin terbuat dari baja dengan diameter $300 \mathrm{~mm}$ dan memiliki berat antara 22 sampai $30 \mathrm{~kg}$

c. Cylindrical Steel Cup memiliki diameter dalam $102 \mathrm{~mm}$ dan kedalaman 50mm. Ketebalan cup tidak lebih dari $6 \mathrm{~mm}$ 
d. Palu baja yang digunakan memiliki berat antara 13,5 sampai $14,0 \mathrm{~kg}$ dengan bagian bawah (bidang kontak) merupakan lingkaran dan berbentuk datar. Diameter kontak sebesar $100 \mathrm{~mm}$ dan ketebalan $50 \mathrm{~mm}$, dengan chamfer 1,5 $\mathrm{mm}$. Palu diatur sedemikian rupa hingga dapat naik turun dengan mudah tanpa gesekan berarti. Palu baja bergerak jatuh bebas dengan tinggi jatuh $380 \pm 5 \mathrm{~mm}$, diukur dari bidang kontak palu sampai permukaan sampel di dalam cup

e. Alat pengunci palu dapat diatur sedemikian rupa untuk dapat memudahkan pergantian sampel dan pemasangan cup

f. Saringan dengan diameter $14,0 \mathrm{~mm}, 10 \mathrm{~mm}$, dan $2,36 \mathrm{~mm}$

g. Besi penusuk dengan panjang $230 \mathrm{~mm}$ serta memiliki potongan melintang lingkaran berdiameter $10 \mathrm{~mm}$

h. Timbangan dengan ketelitian 0,1 gram

\subsubsection{Benda Uji}

a. Sampel yang digunakan adalah agregat yang lolos saringan $14,0 \mathrm{~mm}$ dan yang tertahan saringan 10,0 $\mathrm{mm}(3 / 8 ")$. Untuk setiap pengujian dibuat 2 sampel.

b. Saring antara 500 sampai 1000 gram agregat pada urutan saringan $14,0 \mathrm{~mm}$ dan $10,0 \mathrm{~mm}$ selama 10 menit. Sampel yag diambil adalah agregat yang lolos saringan $14,0 \mathrm{~mm}$ dan tertahan $10,0 \mathrm{~mm}$.

c. Cuci sampel dengan air yang mengalir dan keringkan dalam oven $(110 \pm 5)^{\circ} \mathrm{C}$ selama 4 jam (kondisi kering oven).

d. Setelah suhu turun atau sama dengan suhu ruangan $\left(25^{\circ} \mathrm{C}\right)$ sampel siap untuk digunakan.

\subsubsection{Prosedur Pengerjaan}

a. Timbang cup (Cylindrical Steel Cup) dengan ketelitian 0,1 gram (W1);

b. Isilah cup dengan sampel dalam sampel tiga lapis yang sama tebal. Setiap lapis dipadatkan dengan 25 kali tusukan besi penusuk secaraerata diseluruh permukaan. Tiap lapis tongkat dijatuhkan secara bebas dengan ketinggian lebih dari $5 \mathrm{~cm}$ dari permukaan lapisan. Pada lapisan terakhir isi cup dengan agregat agak menyembul dan padatkan;

c. Ratakan permukaan sampel dengan besi penusuk dan timbang (W2);

d. Hitunglah berat awal sampel $\left(\mathrm{A}^{`}=\mathrm{W} 2-\mathrm{W} 1\right)$;

e. Letakkan mesin Impact agregat pada lantai dasar dan keras seperti lantai beton;

f. Letakkan cup berisi sampel pada tempatnya dan pastikan letak cup sudah baik dan tidak akan bergeser akibat tumbukan palu;

g. Atur ketinggian palu agar jarak antara bidang kontak palu dengan permukaan sampel $380 \pm 5$ $\mathrm{mm}$;

h. Lepaskan pengunci palu dan biarkan palu jatuh bebas ke sampel. Angkat palu pada posisi semula dan lepaskan kembali (jatuh bebas). Tumbukan dilakukan sebanyak 15 kali dengan tenggang waktu tumbukan tidak kurang dari satu detik;

i. Setelah selesai saring benda uji dengan saringan $2,36 \mathrm{~mm}$ satu menit dan timbang berat yang lolos dengan ketelitian 0,1 gram yang dinyatakan sebagai B gram dan yang tertahan sebagai $\mathrm{C}$ gram. Pastikan tidak ada partikel yang hilang selama proses tersebut. Jika selisih jumlah berat agregat yang lolos dan tertahan (A) dengan berat awal (A`) lebih dari 1 gram maka pengujian harus diulang.

\subsubsection{Perhitungan}

Nilai Impact Agregat dinyatakan dengan rumus :

$$
\mathrm{AIV}=\mathrm{x} 100 \%
$$


Dimana :

$$
\begin{aligned}
\text { AIV } & =\text { Aggregate Impact Value }(\%) \\
\text { A } & =\text { berat awal benda uji (gram) } \\
\mathrm{B} & =\text { Berat benda uji lolos saringan } 2,36 \mathrm{~mm} \text { (gram) }
\end{aligned}
$$

\section{PROSEDUR PENELITIAN}

\subsection{Pengumpulan Data}

Metoda yang digunakan adalah dengan melakukan studi literatur dan studi ekperimental perencanaan campuran beraspal panas menggunakan aspal pen 60/70 untuk lapis aus (AC-WC). Penelitian dapat dilaksanakan dengan mempersiapkan program kerja dan langkah-langkah untuk pelaksanaan eksperimen di labortorium. Program kerja meliputi meliputi pengujian agregat, pengujian aspal,penentuan proporsi agregat, penentuan kombinasi campuran, kadar aspal dan mendapatkan job mix formula, serta pengujian stabilitas dan kelelehan dengan alat Marshall, kemudian dilakukan analisa berdasarkan data yang diperoleh. Program kerja secara umum dapat dilihat pada bagan alir pada gambar 2 .

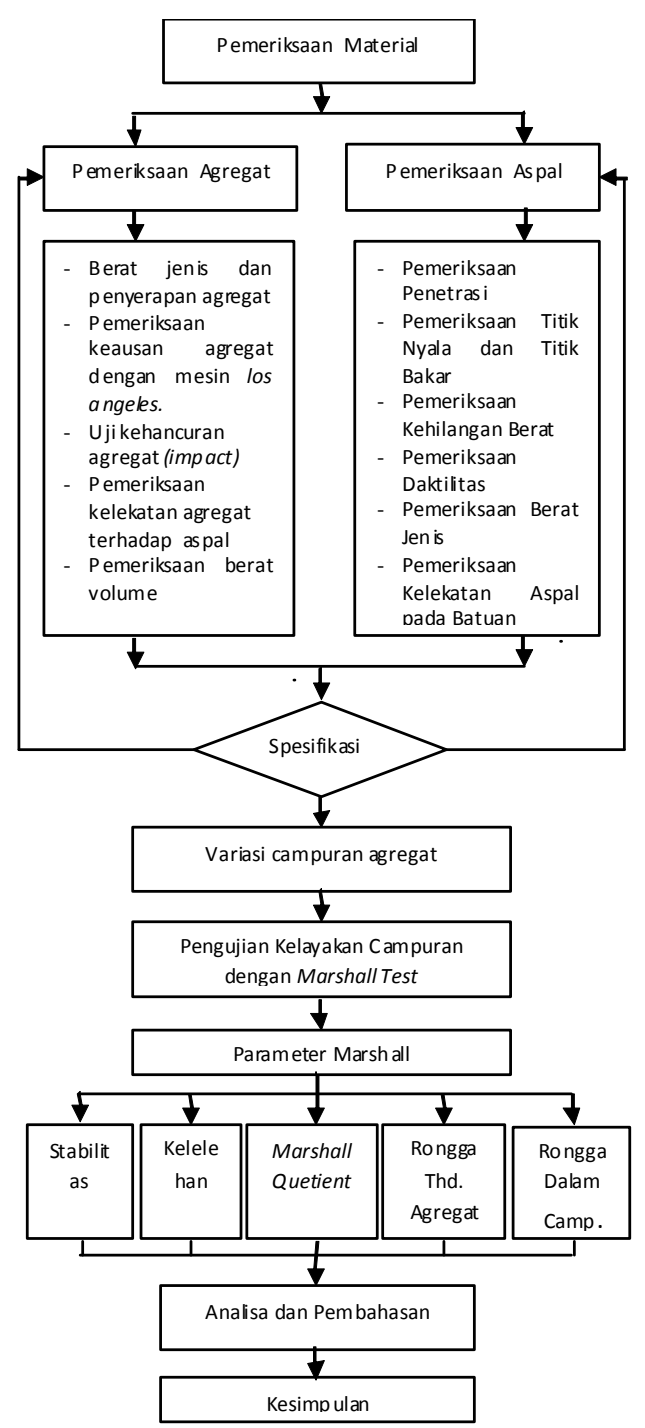

Gambar 2. Diagram Metodelogi Penelitian 


\subsection{Pengujian Laboratorium}

Pengujian laboratorium dilakukan dalam dua tahap yaitu pengujian terhadap material - material pembentuk campuran dan pengujan terhadap campuran. Pembuatan campuran dilaksanakan secara panas atau hot mix.

\subsubsection{Pengujian Material}

1. Pemeriksaan Agregat. Pemeriksaan agregat meliputi:

a. Pemeriksaan berat jenis dan penyerapan agregat. Bertujuan untuk menetukan berat jenis bulk (bulk specific gravity), berat jenis kering permukaan (saturated surface dry), berat jenis semu (apparent specific gravity) dan penyerapan.

b. Pemeriksaan keausan dengan mesin Los Angeles. Bertujuan untuk memeriksa daya tahan agregat terhadap beban mekanis

c. Uji kehancuran agregat. Bertujuan untuk menentukan kekuatan agregat terhadap tumbukan (Aggregat Impact Value).

d. Pemeriksaan kelekatan agregat terhadap aspal. Bertujuan untuk menentukan persentase luas permukaan agregat yang tertutup aspal terhadap seluruh luas permukaan agregat.

e. Pemeriksaan berat isi agregat. Bertujuan untuk mengetahui perbandingan agregat terhadap isi.

2. Pemeriksaan Aspal. Pemeriksaan aspal meliputi:

a. Pemeriksaan penetrasi aspal. Dimaksudkan untuk menentukan penetrasi aspal keras atau lunak dengan menggunakan jarum penetrasi, beban dan waktu tertentu pada suhu tertentu.

b. Pemeriksaan titik nyala dan titik bakar. Bertujuan untuk mengetahui berapa suhu pada saat titik nyala dan titik bakar.

c. Pemeriksaan kehilangan berat. Bertujuan menetukan berapa kehilangan berat aspal mulamula dengan aspal setelah di oven selama 5 jam pada suhu $163{ }^{\circ} \mathrm{C}$.

d. Pemeriksaan daktilitas. Dimaksudkan untuk mengetahui jarak terpanjang yang dapat ditarik antara dua cetakan yang berisi aspal sebelum putus.

e. Pemeriksaan berat jenis. Bertujuan untuk mengetahui perbandingan antara berat aspal dengan berat air suling dengan isi yang sama pada suhu tertentu.

f. Pemeriksaan kelekatan aspal pada batuan. Bertujuan untuk mengetahui kelekatan aspal pada batuan tertentu.

\subsubsection{Menentukan Fraksi Agregat}

Persentase fraksi agregat yang digunakan dalam penelitian ini disesuaikan dengan spesifikasi campuran yang digunakan yaitu campuran Aspal Beton jenis AC-WC (Asphalt Concrete Wearing Course) gradasi halus.

\subsubsection{Campuran yang Direncanakan untuk Menentukan Kadar Aspal Optimum}

Pada penelitian ini dilakukan pemilihan kombinasi penggunaan agregat berdasarkan nilai impactnya untuk fraksi agregat kasar. Dengan filler yang sama untuk semua benda uji yaitu semen portland. Kombinasi campuran material untuk benda uji yaitu :

1. Campuran 1. Campuran ini menggunakan batu pecah sebagai agregat kasar yang berasal dari daerah Lubuk Sikaping, dan pasir sebagai agregat halus, dan aspal. Gradasi agregat didapatkan dari batas tengah Asphalt Concrete - Wearing Course (AC-WC) gradasi halus. 
2. Campuran 2. Campuran ini menggunakan batu pecah sebagai agregat kasar yang berasal dari daerah Padang, pasir sebagai agregat halus, dan aspal sebagai bahan pengikatnya. Gradasi agregat didapatkan dari batas tengah spesifikasi Asphalt Concrete - Wearing Course (AC-WC) gradasi halus.

3. Campuran 3. Campuran ini menggunakan batu pecah sebagai agregat kasar yang berasal dari daerah Ladang Panjang, pasir sebagai agregat halus, dan aspal sebagai bahan pengikatnya. Gradasi agregat didapatkan dari batas tengah spesifikasi Asphalt Concrete Wearing Course (AC-WC) gradasi halus.

4. Campuran 4. Campuran ini menggunakan batu pecah sebagai agregat kasar yang berasal dari daerah Kinali, pasir sebagai agregat halus dan aspal sebagai bahan pengikatnya. Gradasi agregat didapatkan dari tengah Asphalt Concrete - Wearing Course (AC-WC) gradasi halus.

\subsubsection{Menentukan Kadar Aspal}

Dalam penelitian ini kadar aspal pendahuluan ditentukan dengan menggunakan metode luas permukaan. Langkah-langkah dari metode luas permukaan adalah sebagai berikut:

1. Tentukan nilai perbandingan berat jenis agregat standar $(=2,65)$ dengan berat jenis agregat yang diperiksa $(S)$ sesuai dengan kombinasi masing-masing campuran. Secara empiris $S$ dapat dinyatakan dalam persamaan 1 .

$$
\begin{aligned}
& S=2,65 / B J_{\text {Agregat }} \\
& B J_{\text {Agregat }}=\frac{100}{\frac{\% A k}{B J A k}+\frac{\% A h}{B J A h}+\frac{\% \text { filler }}{B J \text { filler }}}
\end{aligned}
$$

2. Tentukan nilai faktor kekasaran permukaan $(\mathrm{K})$. Faktor kekasaran $(\mathrm{K})$ dapat ditentukan sesuai dengan jenis permukaan lapisan penutup yang diinginkan sesuai dengan Tabel 3.1 berikut ini.Keterangan, berselubung pada butir adalah suatu lapisan penutup mengkilat, berdebu, biasanya pada permukaan terbuka.

Tabel 3. Nilai Faktor Kekasaran Permukaan (K)

\begin{tabular}{|l|l|}
\hline Jenis Permukaan & $\mathrm{K}$ \\
\hline Licin mengkilat & 0,85 \\
Berselubung sedikit-sedikt, licin, bundar & 0,90 \\
Berselubung sedikit-sedikt, licin, teratur & 0,95 \\
Berselubung sedang, tidak teratur & 1,00 \\
Berselubung sedang, kasar & 1,05 \\
Berselubung sedang, bersudut-sudut & 1,10 \\
Berselubung banyak, bersudut-sudut atau sedikit menyerap & 1,15 \\
Berselubung banyak, menyerap & 1,20 \\
Berselubung sangat banyak, menyerap & 1,25 \\
\hline
\end{tabular}

Sumber : Laboratorium Transportasi dan Jalan Raya ,2012

3. Tentukan persentase kebutuhan aspal berdasarkan luas permukaan (T).

4. Maka didapat kebutuhan aspal $(\mathrm{P})=\mathrm{S} \times \mathrm{K} \times \mathrm{T}$. 
5. Langkah selanjutnya adalah melakukan korelasi terhadap harga maksimum (P) tersebut, dengan menguranginya sebesar :
a. $0,5 \%$ untuk pasir aspal.
b. $0,4 \%$ untuk aspal beton yang padat dan ketat.
c. $0,3 \%$ untuk aspal beton yang padat dan renggang.

\subsection{Pengujian Campuran dengan Marshall Test}

Langkah - langkah pelaksanaan pengujian ini adalah penyiapan campuran untuk benda uji Marshall, pembuatan campuran untuk benda uji, dan pengujian campuran untuk benda uji dengan Metoda Marshall. Agregat yang diteliti dipisahkan dengan menggunakan saringan berdasarkan spesifikasi yang digunakan sampai diperoleh berat material yang tertahan di sararingan - saringan tersebut cukup untuk pengujian sehingga didapatkan contoh campuran aspal yang bergradasi menerus sesuai spesifikasi. Parameter Marshall dapat digunakan untuk menentukan kualitas suatu campuran perkerasan jalan yang meliputi:

1. Stabilitas. Stabilitas lapisan perkerasan jalan adalah kemampuan lapisan perkerasan menerima beban lalu lintas tanpa terjadi perubahan bentuk yang tetap, seperti gelombang, alur ataupun bleeding. Untuk campuran Asphalt Concrete - Wearing Course (AC-WC) disyaratkan stabilitas minimum $800 \mathrm{~kg}$. Berdasarkan grafik kadar aspal terhadap stabilitas, kecenderungan yang terjadi adalah jika kadar aspal terlalu sedikit atau terlalu banyak, stabilitas campuran akan menurun.

2. Kelelehan (Flow). Kelelehan didefinisikan sebagai perubahan bentuk tetap yang terjadi pada campuran akibat adanya pembebanan. Kriteria kelelehan untuk campuran Asphalt Concrete Wearing Course (AC-WC) minimal $3 \mathrm{~mm}$. Kecenderungan kelelehan terhadap nilai kadar aspal akan semakin tinggi seiring pertambahan kadar aspal.

3. Rongga dalam Campuran (VIM). Rongga dalam campuran adalah ruang udara yang terjadi diantara partikel agregat yang telah terselubungi aspal dalam campuran yang telah dipadatkan. Rongga ini dinyatakan dalam persen (\%) terhadap volume campuran total. Untuk campuran Asphalt Concrete - Wearing Course (AC-WC) gradasi halus, rongga dalam campuran yang diharapkan bernilai minimum 3,5\% dan maksimal 5,5\%.. Lengkung VIM akan terus menurun dengan bertambahnya kadar aspal sampai secara ultimit mencapai nilai minimum. Secara empiris, rongga dalam campuran dirumuskan seperti persamaan 3.

$$
V I M=\left(1-\frac{\text { Berat Isi }}{\text { BJ Agregat }}\right) \times 100
$$

4. Rongga Antar Mineral Agregat (VMA). Rongga antar mineral agregat adalah rongga udara yang ada diantara partikel agregat dalam campuran yang sudah dipadatkan, termasuk ruang yang terisi. Dengan kata lain rongga antar mineral agregat merupakan ruang yang tersedia untuk menampung volume efektif aspal dan rongga udara yang diperlukan dalam campuran.VMA dinyatakan dalam \% terhadap volume total benda uji. Syarat rongga antar agregat berhubungan dengan ukuran nominal agregat yang digunakan. Untuk campuran Asphalt Concrete - Wearing Course (AC-WC) graasi halus disyaratkan rongga antar agregat sedikitnya $15 \%$ dari volume campuran total.. Lengkung VMA akan turun sampai mencapai nilai minimum dan kemudian kembali bertambah dengan bertambahnya kadar aspal. Secara empiris, rongga antar mineral agregat dirumuskan pada persamaan

$$
V M A=100-\left(\frac{\% \text { Agregat }}{\text { BJ Agregat }} \times \text { Berat Isi }\right)
$$


5. Marshall Quotient (MQ). Marshall Quotien (MQ) adalah perbandingan antara stabilitas dengan kelelehan. Untuk campuran Asphalt Concrete - Wearing Course (AC-WC) gradasi halus, nilai Marshall Quotient (MQ) disyaratkan minimal $250 \mathrm{~kg} / \mathrm{mm}$. MQ merupakan indikator kelenturan yang potensial terhadap keretakan. Campuran yang mempunyai potensi retak lebih tinggi adalah campuran dengan MQ relatif besar. Hal ini disebabkan oleh stabilitas yang terlalu tinggi yang tidak diiringi dengan kelelehan yang tinggi pula.

\section{ANALISIS DAN PEMBAHASAN}

\subsection{Umum}

Pemeriksaan ini dimaksudkan untuk mengetahui kelayakan agregat dalam campuran aspal berdasarkan nilai AIVnya. Selain itu, beberapa pemeriksaan berpengaruh pada penentuan proporsi campuran, seperti: berat jenis agregat dan penetrasi aspal. Prosedur pemeriksaan material pada penelitian ini berpedoman pada Standar Nasional Indonesia (SNI) dan British Standard.

\subsection{Pemeriksaan Material}

\subsubsection{Pemeriksaan Agregat}

\section{Nilai Kehancuran Agregat (BS 812: Part 112: 1990)}

Pada pemeriksaan diperoleh nilai Aggregate Impact Value (AIV) kombinasi (1) 4,98\%, (2) $14,00 \%$, (3) $19,01 \%$, (4) $21,84 \%$. Hal ini menunjukkan agregat yang diperiksa masih cukup kuat untuk menahan tumbukan yang diberikan terhadap agregat tersebut walaupun ada agregat yang memiliki nilai kehancuran yang tinggi.

\section{Berat Jenis (SNI 1969: 2008 dan SNI 1970: 2008 )}

Pada pemeriksaan ini didapatkan berat jenis agregat kasar untuk AIV $=4,98 \%$ adalah 2,573 , AIV= $14,00 \%$ adalah 2,557 $\mathrm{AIV}=19,01 \%$ adalah 2,505, dan $\mathrm{AIV}=21,84 \%$ adalah 2,502. Pemeriksaan berat jenis agregat halus 2,518 dengan penyerapan 1,874\%.. Berat jenis agregat kasar minimal 2,500 dan penyerapan agregat maksimal 3,00\%. Berdasarkan spesifikasi yang disyaratkan, berat jenis agregat kasar, serta agregat halus dan penyerapan masing - masingnya memenuhi spesifikasi. Agregat yang mempunyai pori yang kecil cukup baik digunakan dalam perkerasan jalan, karena agregat tersebut akan membutuhkan jumlah aspal yang lebih sedikit dibandingkan dengan agregat yang memiliki pori yang besar.

\section{Pemeriksaan Berat Volume}

Pada pemeriksaan ini diperoleh berat volume agregat (1) sebagai berikut:
Dengan Cara Berat Isi Lepas
Dengan Cara Penusukan
$=1,498 \mathrm{~kg} / \mathrm{dm} 3$,
Dengan Cara Penggoyangan
$=1,599 \mathrm{~kg} / \mathrm{dm} 3$,
$=1,611 \mathrm{~kg} / \mathrm{dm} 3$

Berat volume agregat (2) sebagai berikut:

Dengan Cara Berat Isi Lepas

Dengan Cara Penusukan

Dengan Cara Penggoyangan

$$
\begin{aligned}
& =1,448 \mathrm{~kg} / \mathrm{dm} 3 \\
& =1,569 \mathrm{~kg} / \mathrm{dm} 3 \\
& =1,634 \mathrm{~kg} / \mathrm{dm} 3
\end{aligned}
$$


Berat volume agregat (3) sebagai berikut:

$\begin{array}{ll}\text { Dengan Cara Berat Isi Lepas } & =1,461 \mathrm{~kg} / \mathrm{dm} 3 \\ \text { Dengan Cara Penusukan } & =1,570 \mathrm{~kg} / \mathrm{dm} 3 \\ \text { Dengan Cara Penggoyangan } & =1,571 \mathrm{~kg} / \mathrm{dm} 3\end{array}$

Berat volume agregat (4) sebagai berikut:

Dengan Cara Berat Isi Lepas $\quad=1,435 \mathrm{~kg} / \mathrm{dm} 3$

Dengan Cara Penusukan $\quad=1,544 \mathrm{~kg} / \mathrm{dm} 3$

Dengan Cara Penggoyangan $\quad=1,582 \mathrm{~kg} / \mathrm{dm} 3$

Dari hasil pemeriksaan berat volume ini kita dapat menentukan jumlah agregat yang akan digunakan persatuan volume. Dengan diketahuinya panjang jalan, lebar jalan dan tebalnya perkerasan akan diperoleh jumlah agregat yang akan digunakan. Dan dengan diketahuinya berat volume ini maka dapat diketahui cara pemadatan yang optimum pada lapisan jalan.

\section{Pemeriksaan Kelekatan Agregat Terhadap Aspal (SNI 06-2439-1991)}

Dari hasil pengamatan diperoleh :

$\begin{array}{ll}\text { Nilai kelekatan agregat (1) } & =97 \% \\ \text { Nilai kelekatan agregat (2) } & =96 \% \\ \text { Nilai kelekatan agregat (3) } & =98 \% \\ \text { Nilai kelekatan agregat (4) } & =97 \%\end{array}$

Hal ini menunjukkan bahwa agregat yang diperiksa baik untuk bahan perkerasan jalan. Agregat dengan permukaan yang kasar dan berpori lebih baik daya lekatnya terhadap aspal dibandingkan dengan agregat yang permukaannya licin.

\section{Pemeriksaan Keausan dengan Mesin Los Angeles (SNI 2417: 2008)}

Pada pemeriksaan ini diperoleh nilai keausan agregat kasar kombinasi (1) adalah 17,96\%, (2) $28,589 \%$, (3) $39,142 \%$, (4) $44,231 \%$. Hal ini menunjukkan agregat yang diperiksa masih cukup kuat untuk menahan gaya gesek yang diberikan terhadap agregat tersebut. Bina Marga menyarankan nilai keausan maksimum adalah $40 \%$. Kecuali agregat kombinasi 4 dengan AIV = $21,84 \%$.

\subsubsection{Pemeriksaan Aspal}

\section{Penetrasi (SNI 06-2456)}

Pada percobaan ini diperoleh nilai penetrasi aspal tanpa kehilangan berat dan penetrasi kehilangan berat berkisar antara $6.0 \mathrm{~mm}-7.0 \mathrm{~mm}$. Jadi nilai penetrasi aspal digolongkan sebagai Pen 60/70.

\section{Kehilangan Berat Aspal (SNI 06-2440-1991)}

Pada percobaan ini diperoleh kehilangan berat aspal sebesar $0,175 \%$. Persentase ini menunjukkan besarnya kehilangan berat aspal akibat penguapan yang terjadi. Dari percobaan ini dapat disimpulkan bahwa aspal yang digunakan dalam kondisi baik. Penurunan berat aspal yang besar akan menyebabkan aspal menjadi getas dan rapuh. 


\section{Titik Nyala dan Titik Bakar (SNI 06-2433-1991)}

Pada pemeriksaan ini didapatkan nilai titik nyala $285^{\circ} \mathrm{C}$ dan titik bakar $332{ }^{\circ} \mathrm{C}$. Pemeriksaan titik nyala dan titik bakar ini perlu diketahui untuk mengetahui suhu maksimum yang diperbolehkan pada aspal sehingga aspal tidak terbakar. Jika melebihi suhu pada saat aspal terbakar maka hal ini akan mempengaruhi struktur dan sifat kimia dari aspal itu sendiri. Maka dari itu suhu pencampuran harus berada dibawah suhu titik nyala.

\section{Pemeriksaan Daktilitas (SNI 06-2432-1991)}

Pada pemeriksaan ini diperoleh nilai daktilitas $>1100 \mathrm{~mm}$. Aspal dengan daktilitas yang lebih besar mengikat butir-butir agregat lebih baik, tetapi lebih peka terhadap perubahan temperatur.

\section{Berat Jenis (SNI 06-2441-1991)}

Pada pemeriksaan ini diperoleh berat jenis aspal sebesar 1,025. Berat jenis yang disyaratkan minimal 1. Jadi berat jenis aspal yang digunakan sesuai dengan spesifikasi. Nilai berat jenis ini digunakan dalam perencanaan campuran untuk suatu lapisan perkerasan lentur, karena dengan berat jenis aspal ini kita dapat menentukan peresentase aspal atau besar kecilnya volume dari aspal.

\section{Pemeriksaan Kelekatan Aspal Terhadap Batuan (PA 0312-76)}

Kelekatan aspal terhadap agregat besar dari 95\%, ini berarti aspal memiliki daya lekat yang cukup tinggi terhadap agregat, dan aspal ini baik digunakan untuk campuran perkerasan jalan.

\subsection{Analisis Parameter Marshall dengan Pada Kombinasi Campuran}

Macam-macam kombinasi yang dibandingkan yaitu :

1. Campuran 1. Campuran ini menggunakan batu pecah yang diambil dari Lubuk Sikaping dengan nilai $\mathrm{AIV}=4,98 \%$ sebagai agregat kasar, pasir sebagai agregat halus, semen sebagai filler, dan aspal. Gradasi agregat didapatkan dari batas tengah Asphalt Concrete - Wearing Course (AC-WC) gradasi halus.

2. Campuran 2. Campuran ini menggunakan batu pecah yang diambil dari Padang dengan nilai AIV $=14,00 \%$ sebagai agregat kasar, pasir sebagai agregat halus, semen sebagai filler, dan aspal. Gradasi agregat didapatkan dari batas tengah Asphalt Concrete - Wearing Course (AC-WC) gradasi halus.

3. Campuran 3. Campuran ini menggunakan batu pecah yang diambil dari Ladang Panjang dengan nilai $\mathrm{AIV}=19,01 \%$ sebagai agregat kasar, pasir sebagai agregat halus, semen sebagai filler, dan aspal. Gradasi agregat didapatkan dari batas tengah Asphalt Concrete - Wearing Course (AC-WC) gradasi halus.

4. Campuran 4. Campuran ini menggunakan batu pecah yang diambil dari Lubuk Sikaping dengan nilai $\mathrm{AIV}=21,84 \%$ sebagai agregat kasar, pasir sebagai agregat halus, semen sebagai filler, dan aspal. Gradasi agregat didapatkan dari batas tengah Asphalt Concrete - Wearing Course (AC-WC) gradasi halus.

\section{A. Stabilitas}

Perbandingan hasil pengujian stabilitas benda uji campuran menggunakan agregat dengan nilai AIV yang berbeda dapat dilihat pada Gambar 3. Hasil pengujian menunjukan bahwa nilai puncak: Stabilitas campuran dengan AIV $=4,98 \%>$ Stabilitas campuran dengan AIV $=14,00 \%>$ Stabilitas campuran dengan $\mathrm{AIV}=19,01 \%>$ Stabilitas campuran dengan $\mathrm{AIV}=21,84 \%$. 
Berdasarkan spesifikasi Asphalt Concrete - Wearing Course (AC-WC) disyaratkan stabilitas minimum $800 \mathrm{~kg}$. Pengujian diatas menunjukan bahwa tidak semua nilai stabilitas campuran memenuhi spesifikasi. Campuran dengan $\mathrm{AIV}=4,98 \%$ dan $\mathrm{AIV}=14,00 \%$ mempunyai nilai stabilitas yang memenuhi spesifikasi pada kadar aspal kecil dari 9,00\%. Sedangkan campuran dengan $\mathrm{AIV}=19,00 \%$ dan $\mathrm{AIV}=21,84 \%$ mempunyai nilai stabilitas yang memenuhi spesifikasi masing - masingnya pada kadar aspal kecil dari 6,40\% dan 6,60\%.

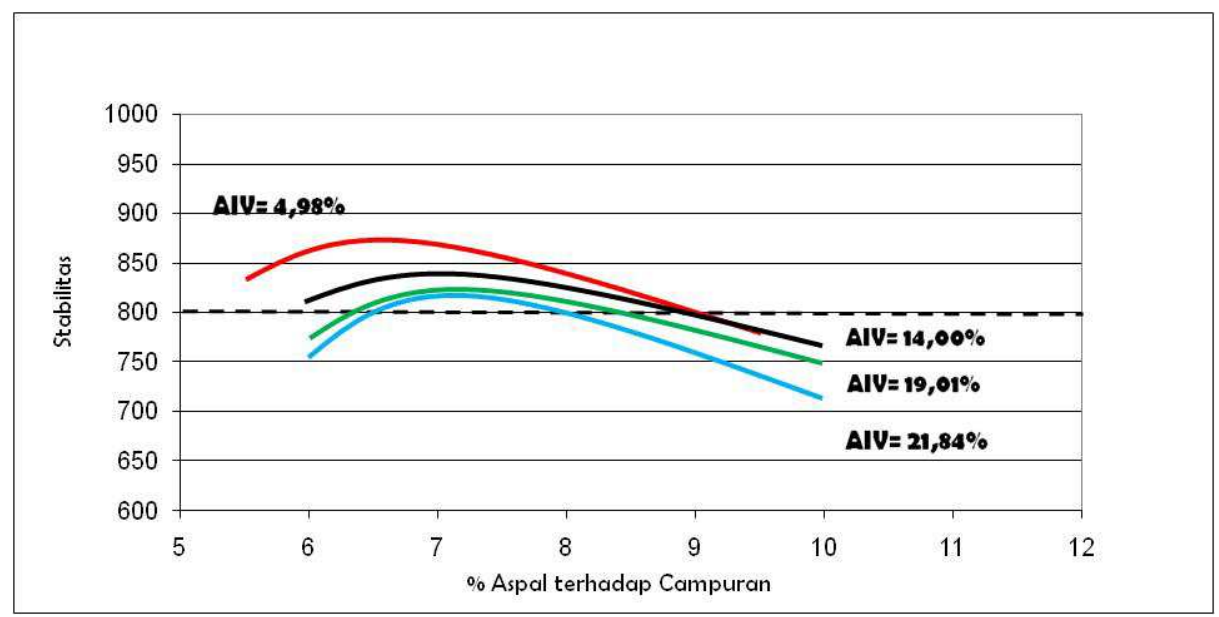

Gambar 3. Hubungan antara Kadar Aspal Campuran dengan Stabilitas

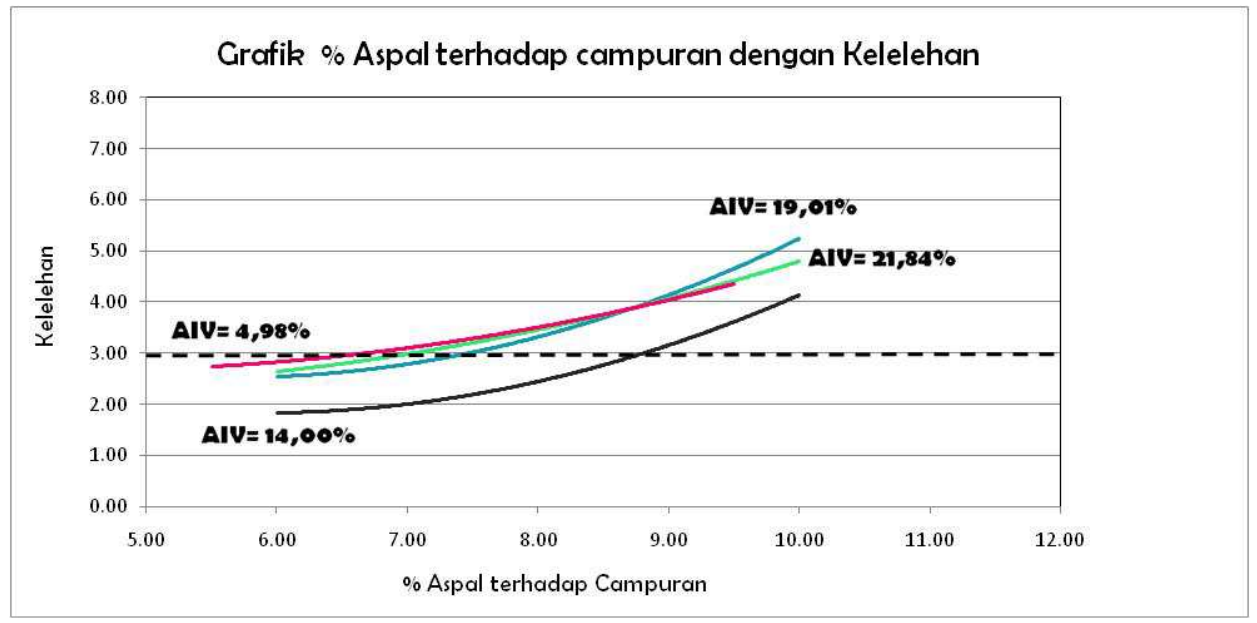

Gambar 4. Hubungan antara Kadar Aspal Campuran dengan Kelelehan

Stabilitas adalah kemampuan lapisan perkerasan menerima beban lalu lintas tanpa terjadi perubahan bentuk yang tetap. Stabilitas merupakan indikator durabilitas atau keawetan. Dimana stabilitas berbanding lurus dengan durabilitas. Semakin tinggi nilai stabilitas maka perkerasan akan dapat menerima beban yang semakin tinggi sehingga durabilitas akan semakin tinggi.

\section{B. Kelelehan}

Dari hasil pengujian terhadap campuran menggunakan agregat dengan nilai AIV yang berbeda didapatkan perbandingan nilai kelelehan seperti pada Gambar 4. Dari gambar diatas dapat kita simpulkan bahwa:

Kelelehan campuran dengan AIV $=21,84 \%>$ Kelelehan campuran dengan AIV $=19,01 \%>$ Kelelehan campuran dengan $\mathrm{AIV}=4,98 \%>$ Kelelehan campuran dengan AIV $=14,00 \%$. 
Berdasarkan spesifikasi Asphalt Concrete - Wearing Course (AC-WC) disyaratkan kelelehan minimum $3 \mathrm{~mm}$. Dari gambar tersebut dapat dilihat tidak semua nilai kelelehan campuran masuk ke dalam spesifikasi. Campuran dengan $\mathrm{AIV}=4,98 \%$ mempunyai nilai kelelehan yang memenuhi spesifikasi pada kadar aspal besar dari 6,50 \% . campuran dengan AIV $=14,00 \%$ mempunyai nilai kelelehan yang memenuhi spesifikasi besar dari 8,80 \% . Campuran dengan AIV= 19,01 \% mempunyai nilai kelelehan yang memenuhi spesifikasi pada kadar aspal besar dari $7,20 \%$. Sedangkan campuran dengan nilai $\mathrm{AIV}=21,84 \%$ mempunyai nilai kelelehan yang memenuhi spesifikasi pada kada aspal besar dari 7,40\%.

Kelelehan merupakan indikator kelenturan atau fleksibilitas. Fleksibilitas merupakan kemampuan beton aspal untuk menyesuaikan diri akibat penurunan dan pergerakan dari pondasiatau tanah dasar, tanpa terjadi retak. Dimana fleksibilitas yang tinggi disebabkan oleh kadar aspal yang tinggi, sedangkan kadar aspal yang tinggi mengakibatkan kelelehan yang tinggi. Dengan demikian kelelehan berbanding lurus dengan fleksibilitas. Semakin tinggi nilai kelelehan maka fleksibilitas akan semakin tinggi.

\section{VIM (Void In Mix)}

Dari hasil pengujian terhadap campuran menggunakan agregat dengan nilai AIV yang berbeda didapatkan perbandingan nilai VIM seperti pada Gambar 5.

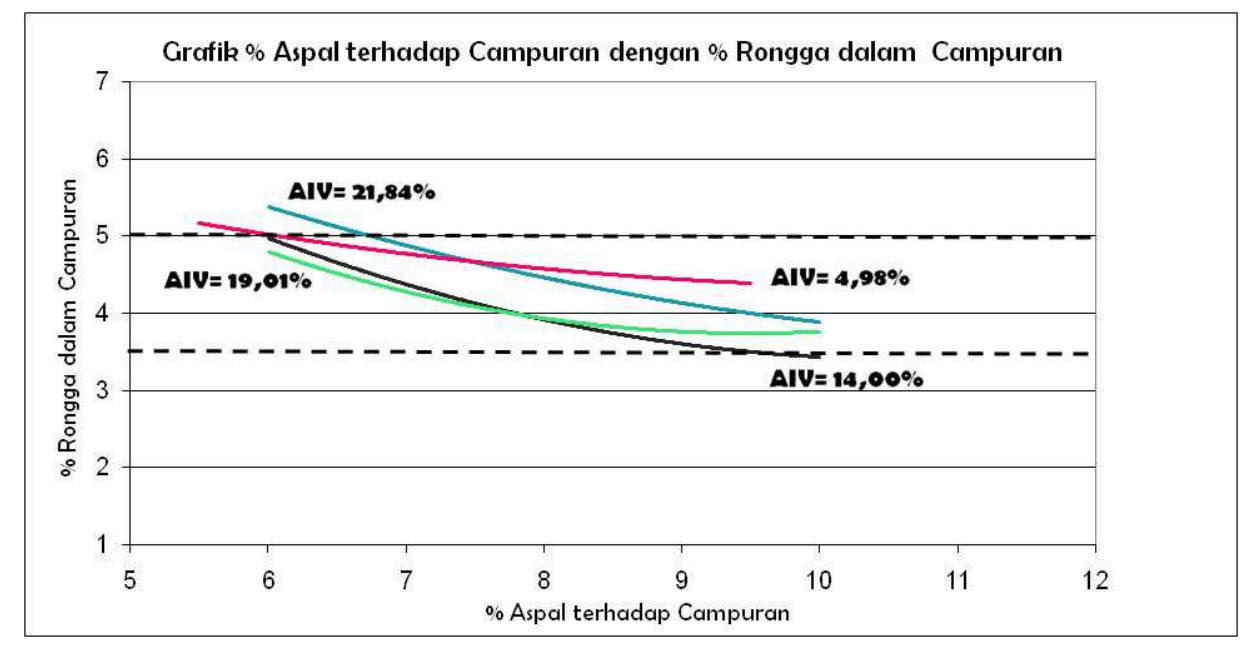

Gambar 5. Hubungan antara Kadar Aspal Campuran dengan VIM

Dari gambar diatas terlihat bahwa VIM campuran dengan AIV $=21,84 \%<$ VIM campuran dengan $\mathrm{AIV}=4,98 \%<\mathrm{VIM}$ campuran dengan AIV $=14,00 \%$ > VIM campuran dengan AIV $=19,01 \%$. Berdasarkan spesifikasi Asphalt Concrete - Wearing Course (AC-WC) disyaratkan nilai VIM minimal 3,50 \% dan maksimal 5,00 \%. Campuran dengan AIV=19,01 \% mempunyai nilai VIM yang memenuhi spesifikasi. Campuran dengan AIV= 4,98 \% yang memenuhi spesifikasi pada kadar aspal besar dari 6,50 \%. Campuran dengan AIV=14,00 \% mempunyai nilai VIM yang memenuhi spesifikasi pada kadar aspal 6,00 \% - 9,40\%. Sedangkan campuran dengan AIV= $21,84 \%$ yang memenuhi spesifikasi pada kadar aspal besar dari 6,80\%.

VIM merupakan indikator dari durabilitas, VIM yang terlalu besar akan mengakibatkan beton aspal padat berkurang kekedapan airnya, sehingga berakibat meningkatnya proses oksidasi aspal dan mempercepat penuaan aspal dan menurunkan sifat durabilitas aspal. VIM yang terlalu kecil akan mengakibatkan perkerasan mengalami bleeding jika temperatur meningkat. 


\section{Marshall Quotient (MQ)}

Hasil pengujian MQ terhadap benda uji dapat dilihat pada Gambar 6.

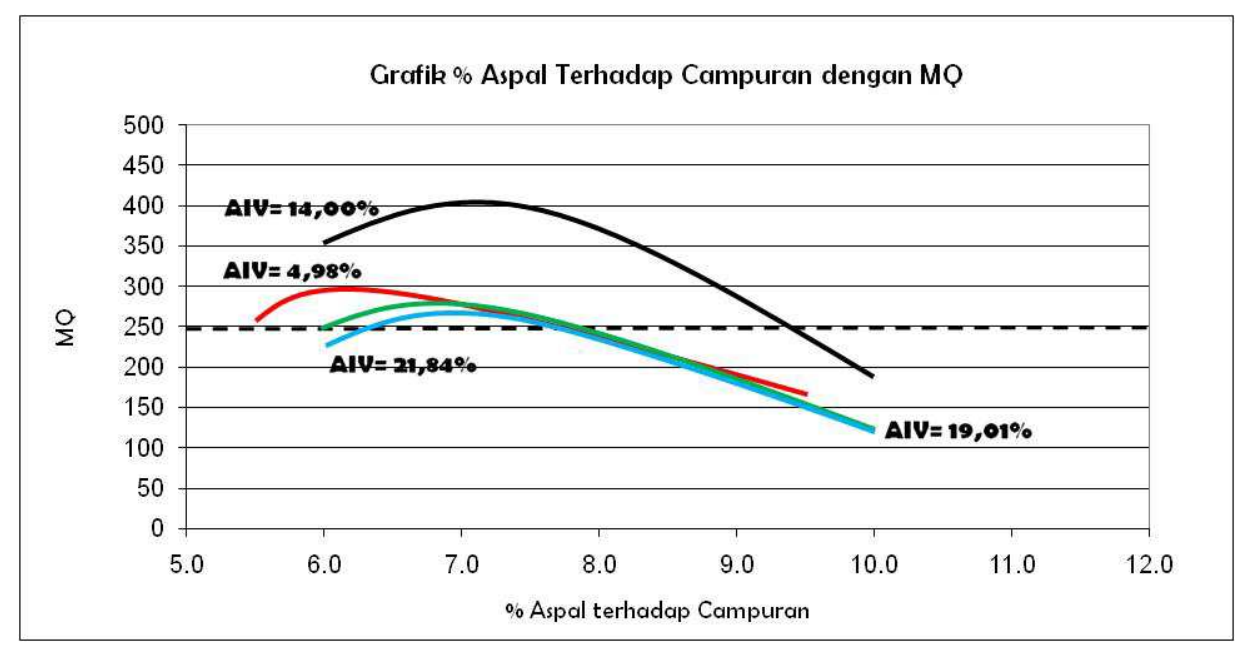

Gambar 6. Hubungan antara Kadar Aspal Campuran dengan MQ

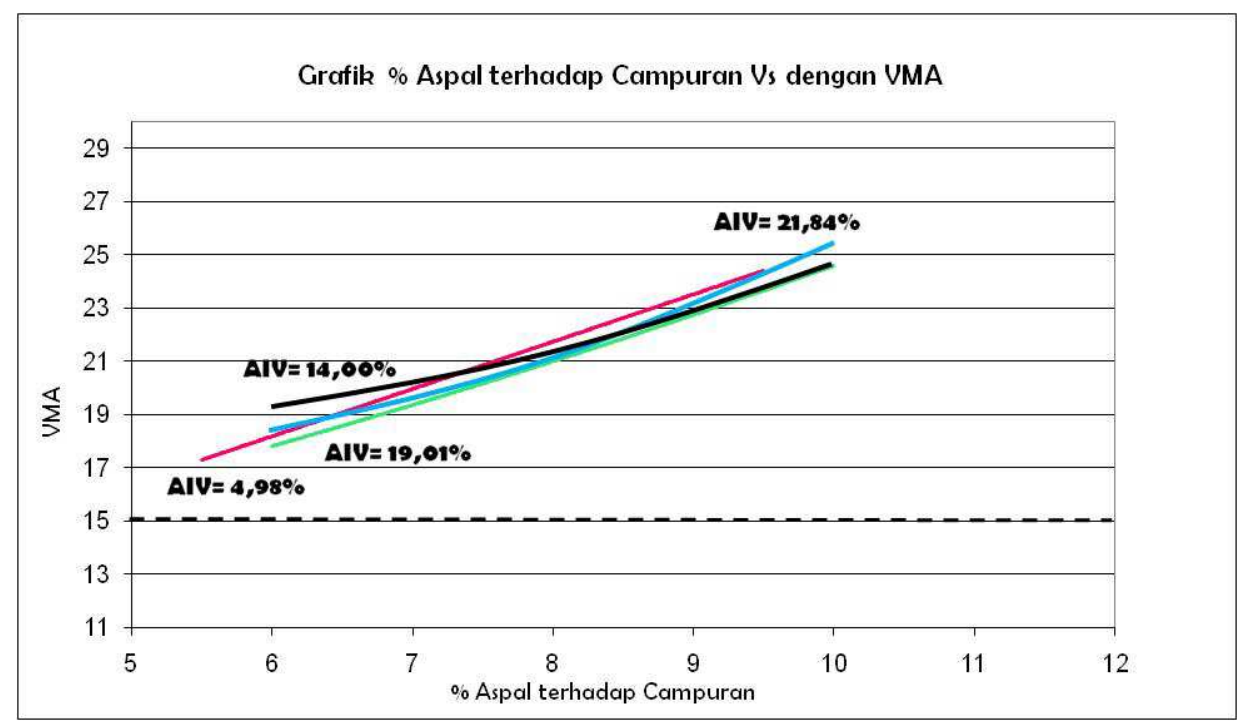

Gambar 7. Hubungan antar Kadar Aspal Campuran dengan VMA

Dari gambar tersebut terlihat bahwa MQ campuran dengan AIV=14,00\% > MQ campuran dengan $\mathrm{AIV}=4,98 \%>\mathrm{MQ}$ campuran dengan AIV = 19,01 \%> MQ campuran dengan AIV= 21,84\% . Campuran Asphalt Concrete - Wearing Course (AC-WC) gradasi halus mensyaratkan bahwa nilai Marshall Qoutient (MQ) minimum $250 \mathrm{~kg} / \mathrm{mm}$. Tapi dari grafik dapat dilihat tidak semua hasil MQ tersebut memenuhi spesifikasi. Campuran dengan AIV=4,98 \% yang memenuhi spesifikasi pada kadar aspal kecil 7,70\%. Campuran dengan AIV=14,00\% yang memenuhi spesifikasi pada kadar aspal kecil dari 9,40 \%. Campuran dengan $\mathrm{AIV}=19,01 \%$ dan $\mathrm{AIV}=21,84 \%$ yang memenuhi spesifikasi pada kadar aspal kecil dari 8,00\%.

Nilai MQ yang terlalu tinggi akan menyebabkan perkerasan menjadi getas, sedangkan nilai MQ yang terlalu kecil akan menyebabkan perkerasan menjadi lunak sehingga perkerasan tidak mampu menahan beban yang terlalu tinggi. Dengan demikian nilai MQ yang terlalu besar ataupun terlalu kecil tidak baik untuk perkerasan.

66 | JURNAL REKAYASA SIPIL 


\section{E. VMA (Void in the Mineral Agregat)}

Hasil penelitian terhadap rongga dalam agregat (VMA) menggunakan agregat dengan nilai AIV yang berbeda dapat dilihat pada Gambar 7. Dari gambar diatas terlihat bahwa: VMA campuran dengan $\mathrm{AIV}=21,84 \%$ < VMA campuran dengan $\mathrm{AIV}=4,98 \%>$ VMA campuran dengan AIV= $14,00 \%<$ VMA campuran dengan AIV $=19,01 \%$. Berdasarkan spesifikasi Asphalt Concrete Wearing Course (AC-WC) disyaratkan nilai VMA minimal $15 \%$. Berdasarkan gambar di atas terlihat bahwa semua campuran memenuhi spesifikasi. VMA merupakan indikator durabilitas. Nilai VMA yang semakin tinggi menghasilkan filem aspal yang semakin besar sehingga durabilitas aspal semakin tinggi.

\subsubsection{Kadar Aspal Optimum}

Nilai kadar aspal optimum didapat dari hasil pemeriksaan campuran baik campuran pembanding maupun campuran kombinasi. Dari hasil pemeriksaan campuran ini juga akan didapat nilai masingmasing parameter Marshall, yang nantinya akan menghasilkan kadar aspal optimum yang digunakan dalam campuran tersebut seperti dibawah ini :

$\begin{array}{lll}\text { Campuran 1 } & =7,10 \% \\ \text { Campuran 2 } & =7,50 \% \\ \text { Campuran 3 } & =7,60 \% \\ \text { Campuran 4 } & =7,70 \%\end{array}$

Dari data diatas dapat dilihat bahwa campuran 1 menghasilkan nilai kadar aspal optimum yang rendah. Pada kadar aspal optimum ini, campuran 1 menghasilkan stabilitas yang tinggi. Sehingga apabila ini digunakan dalam perkerasan jalan akan menghasilkan kekuatan yang tinggi yang dapat memikul beban lalu lintas yang berat sehingga tidak terjadi perubahan bentuk tetap seperti gelombang, alur ataupun bleeding. Untuk masing-masing kadar aspal optimum diatas dibuat 3 buah benda uji. Hasil perhitungan dan pemeriksaan benda uji tersebut dapat dilihat pada Tabel 3.

Tabel 3. Perbandingan Parameter Marshall Campuran Kombinasi dengan Kadar Aspal Optimum.

\begin{tabular}{|l|l|l|l|l|l|l|}
\hline Campuran & Kadar Aspal Optimum & Stabilitas & Kelelehan & VIM & MQ & VMA \\
\hline 1 & 7,10 & 838,99 & 3,42 & 4,72 & 256,74 & 20,85 \\
\hline 2 & 7,50 & 815,37 & 2,71 & 4,05 & 346,87 & 21,22 \\
\hline 3 & 7,60 & 790,41 & 3,59 & 4,10 & 235,02 & 21,10 \\
\hline 4 & 7,70 & 769,14 & 3,61 & 4,54 & 234,10 & 21,38 \\
\hline
\end{tabular}

\subsubsection{Pengaruh Nilai Kehancuran Agregat yang Digunakan terhadap Campuran Aspal}

\section{A. Kadar Aspal}

Hasil Pengujian terhadap empat (4) kombinasi yang ada dapat ilihat pada Gambar 8. Berdasarkan gambar di atas terlihat bahwa semakin besar nilai AIV yang digunakan, maka akan semakin besar kadar aspal yang diperlukan. Hal ini disebabkan oleh campuran dengan nilai AIV yang tinggi memiliki agregat dengan pori yang banyak sehingga akan membutuhkan kadar aspal yang tinggi. 


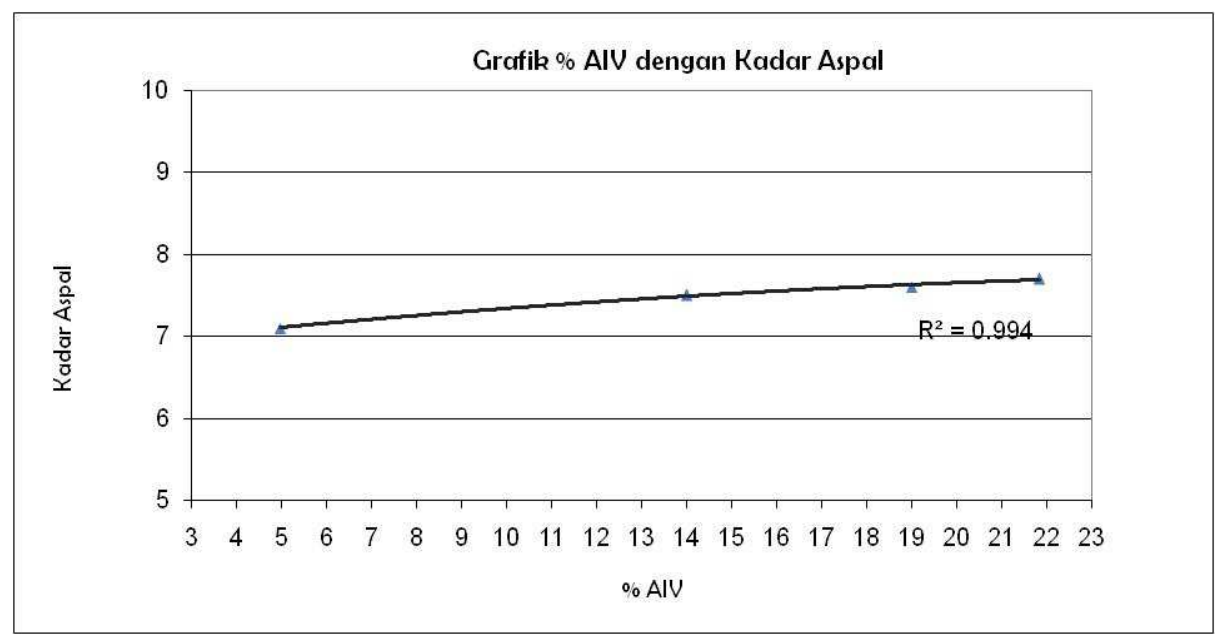

Gambar 8. Hubungan antara AIV dengan Kadar Aspal Campuran

\section{B. Stabilitas}

Nilai stabilitas yang diperoleh dari empat (4) kombinasi dapat dilihat pada gambar 9.

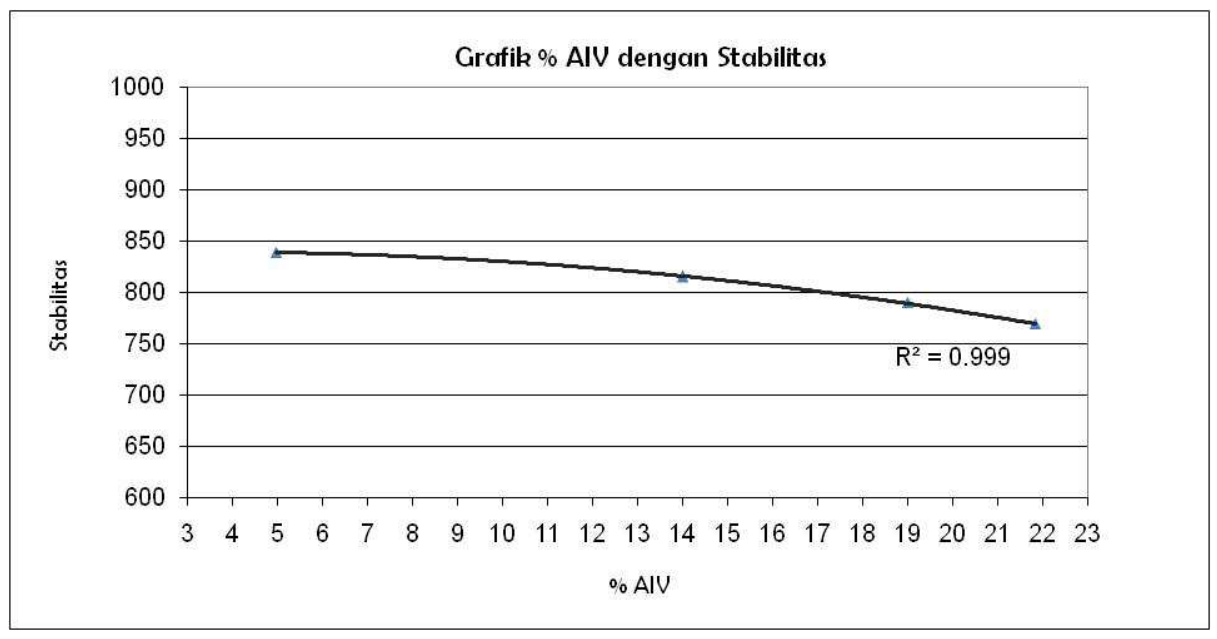

Gambar 9. Hubungan antara AIV dengan Stabilitas

Dari gambar di atas terlihat bahwa semakin kecil nilai AIV yang digunakan, maka stabilitas dari campuran akan semakin tinggi. Hal ini menunjukkan bahwa agregat dengan nilai AIV yang rendah akan lebih kuat dalam menahan beban lalu lintas yang diterimanya.

\section{Kelelehan}

Nilai kelelehan yang diperoleh dari empat (4) kombinasi dapat dilihat pada gambar 10. Dari gambar di atas terlihat bahwa terdapat tiga campuran yang memenuhi spesifikasi untuk kelelehan yang direncanakan yaitu minimal $3 \mathrm{~mm}$. Dengan demikian, untuk agregat yang memenuhi spesifikasi mempunyai fleksibilitas yang tinggi. 


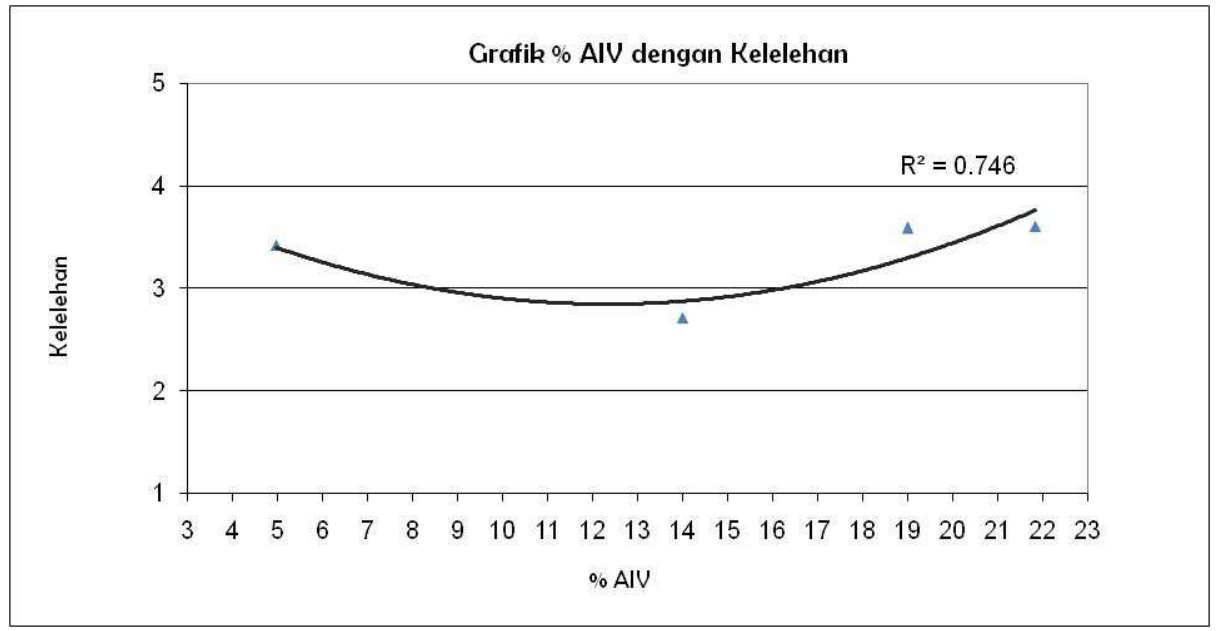

Gambar 10. Hubungan antara AIV dengan Kelelehan

\section{VIM (Void In Mix)}

Nilai VIM yang diperoleh dari empat (4) kombinasi dapat dilihat pada gambar 11.

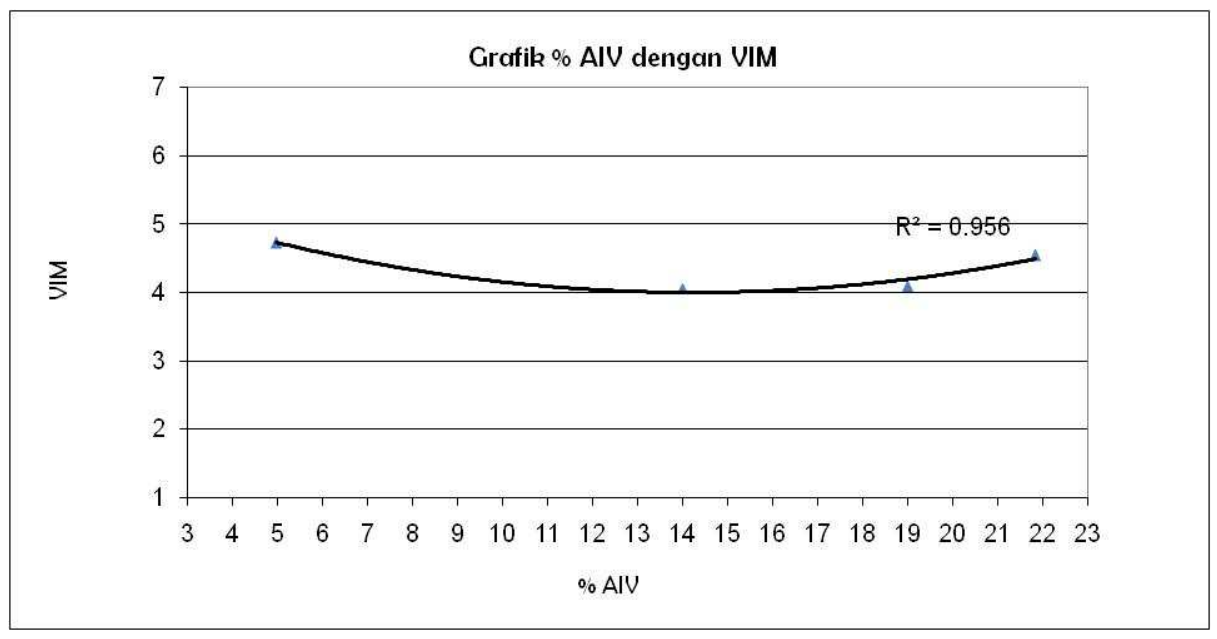

Gambar 11. Hubungan antara AIV dengan VIM

Berdasarkan gambar di atas dapat disimpulkan bahwa semakin besar nilai AIV akan menghasilkan VIM yang kecil. VIM merupakan indikator durabilitas. Dengan demikian, campuran dengan nilai AIV yang rendah memiliki durabilitas yang rendah.

\section{E. MQ (Marshall Quotient)}

Nilai MQ yang diperoleh dari empat (4) kombinasi dapat dilihat pada gambar 12. Berdasarkan gambar di atas terlihat bahwa pada campuran dengan AIV paling rendah memenuhi spesifikasi, kemudian marshall quotient mengalami kenaikan pada batas tertentu dan mengalami penurunan pada campuran dengan AIV tinggi. Berdasarkan gambar tersebut campuran yang baik dipilih campuran dengan AIV yang paling rendah. Hal ini disebabkan marshall quotient tidak terlalu tinggi sehingga tidak mudah getas. 


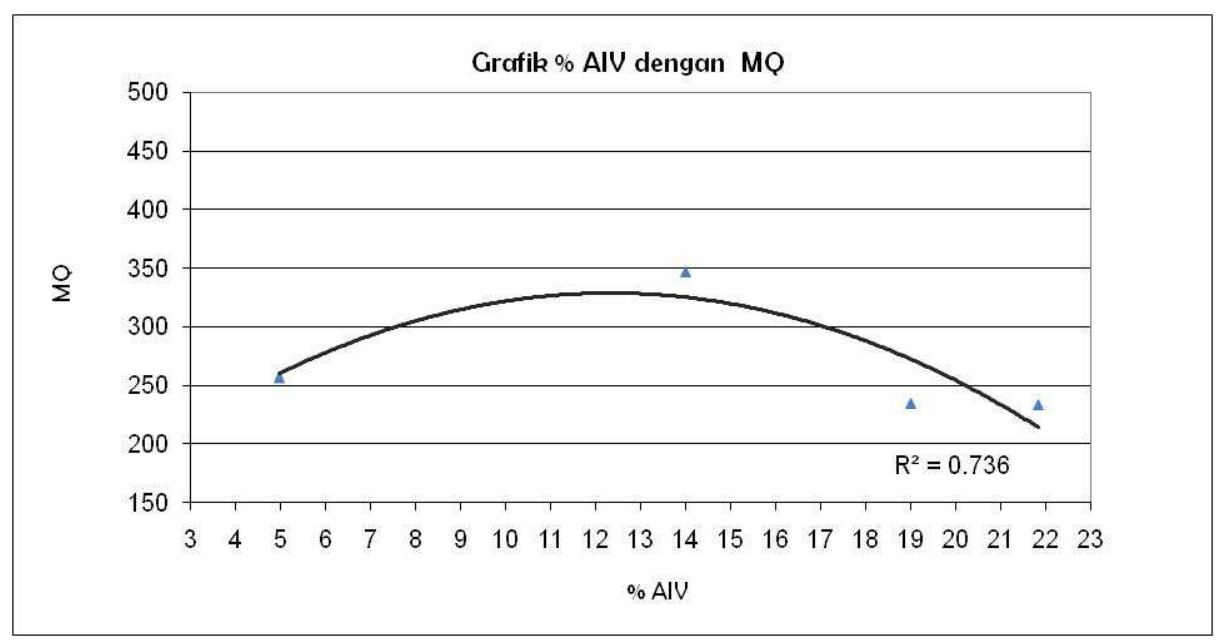

Gambar 12. Hubungan antara AIV dengan MQ

\section{F. VMA (Void In The Mineral Aggregate)}

Nilai VMA yang diperoleh dari empat (4) kombinasi dapat dilihat pada gambar 13. Berdasarkan gambar di atas dapat disimpulkan bahwa semakin besar nilai AIV maka nilai VMA akan semakin besar. VMA merupakan indikator durabilitas. Campuran dengan AIV yang tinggi memiliki durabilitas yang rendah.

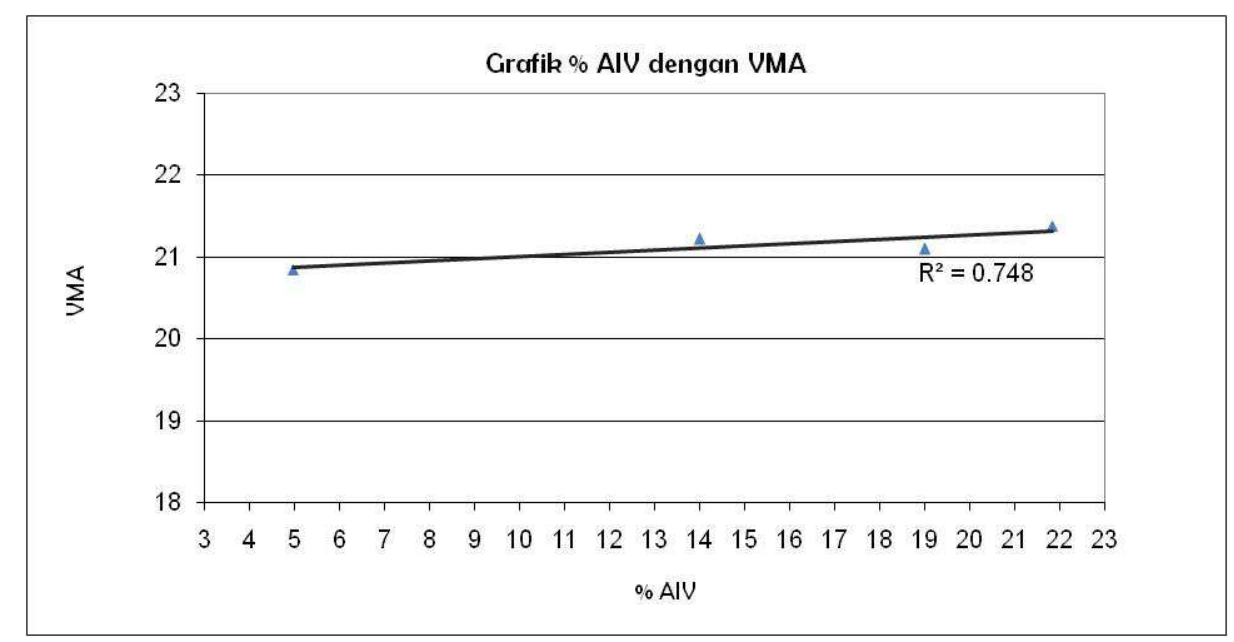

Gambar 13. Hubungan antara AIV dengan VMA

\section{KESIMPULAN}

1. Berdasarkan Parameter Marshall masing - masing kombinasi, penggunaan agregat dengan $\mathrm{AIV}=4,98 \%$ memiliki stabilitas yang tinggi dan kelelehan yang rendah dibandingkan dengan campuran lainnya. Sehingga campuran ini baik digunakan dalam campuran Asphalt Concrete Wearing Course (AC-WC) gradasi halus.

2. Penggunaan agregat dengan AIV yang berbeda akan menghasilkan Parameter Marshall yang berbeda, dimana semakin besar AIV maka kualitas campuran aspal semakin berkurang, ini dapat dilihat pada Parameter Marshall. 
3. Campuran dengan $\mathrm{AIV}=19,01 \%$ dan $\mathrm{AIV}=21,84 \%$ kurang baik digunakan dalam campuran Asphalt Concrete Wearing Course (AC-WC) gradasi halus. Hal ini disebabkan oleh nilai stabilitas yang rendah dibandingkan dengan campuran lainnya.

\section{DAFTAR KEPUSTAKAAN}

Sukirman S, (1993), Perkerasan Lentur Jalan Raya, Nova, Bandung.

Hendarsin S (2000), Perencanaan Teknik Jalan Raya, Politeknik Negri Bandung Jurusan Teknik Sipil, Bandung.

Sukirman S (2003), Beton Aspal Campuran Panas, Granit, Jakarta.

Departemen Pemukiman dan Prasarana Wilayah Direktorat Jenderal Prasarana Wilayah (2004), Pekerjaan Campuran Beraspal Panas. Jakarta.

Kementerian Pekerjaan Umum (2010), Spesifikasi Umum 2010 Divisi 6 Perkerasan Aspal, Jakarta.

Laboratorium Transportasi dan Jalan Raya, Petunjuk Pelaksanaan Praktikum Bahan Perkerasan Jalan Raya, 